\title{
Cardiac Sigma Receptors - An Update
}

\author{
T. STRACINA ${ }^{1}$, M. NOVAKOVA ${ }^{1}$ \\ ${ }^{1}$ Department of Physiology, Faculty of Medicine, Masaryk University, Brno, Czech Republic
}

Received March 25, 2018

Accepted September 12, 2018

\begin{abstract}
Summary
More than four decades passed since sigma receptors were first mentioned. Since then, existence of at least two receptor subtypes and their tissue distributions have been proposed. Nowadays, it is clear, that sigma receptors are unique ubiquitous proteins with pluripotent function, which can interact with so many different classes of proteins. As the endoplasmic resident proteins, they work as molecular chaperones - accompany various proteins during their folding, ensure trafficking of the maturated proteins between cellular organelles and regulate their functions. In the heart, sigma receptor type 1 is more dominant. Cardiac sigma 1 receptors regulate response to endoplasmic reticulum stress, modulates calcium signaling in cardiomyocyte and can affect function of voltage-gated ion channels. They contributed in pathophysiology of cardiac hypertrophy, heart failure and many other cardiovascular disorders. Therefore, sigma receptors are potential novel targets for specific treatment of cardiovascular diseases.
\end{abstract}

\section{Key words}

Sigma receptor • Heart • Chaperone • Endoplasmic reticulum stress

\section{Corresponding author}

M. Novakova, Department of Physiology, Faculty of Medicine, Masaryk University, Kamenice 5, 62500 Brno, Czech Republic. E-mail: majka@med.muni.cz

\section{A brief history - from an enigmatic binding site in the brain to ubiquitous receptor and molecular chaperone}

Sigma receptors were first reported in the central nervous system by Martin and co-workers in 1976
(Martin et al. 1976). The authors believed that sigma receptor represents an opioid receptor subtype, which mediates psychomimetic and stimulatory behavioral effects of N-allylnormetazocine (SKF-10047) in chronic spinal dog. Subsequent binding studies in guinea pig and rat showed that binding profile of sigma receptor differs from any other known subtype of opioid receptor as well as other receptor classes (Su 1982, Tam 1983). Therefore, the sigma receptor was defined as novel receptor type (Su 1982).

\section{Two subtypes of sigma receptor}

Further research led to differentiation among at least two subtypes of sigma receptors. Based on their diverse ligand selectivity and stereospecificity, association with signal transduction mechanism and/or enzyme function, tissue distribution, subcellular localization, and apparent molecular mass, existence of sigma receptor type 1 (sigma 1 receptor) and type 2 (sigma 2 receptor) has been proposed and confirmed (Hellewell and Bowen 1990, Quirion et al. 1992, Torrence-Campbell and Bowen 1996). The sigma receptor originally described by $\mathrm{Su}$ (1982) was recognized as the sigma 1 receptor (Hellewell and Bowen 1990).

Since the molecular structure of the sigma 1 receptor was not known till 1996, various sigma ligands were employed in the studies of distribution and cellular functions of sigma receptors. Selective ligands (e.g. 1,3-di(2-tolyl) guanidine (DTG), SA 4503, $( \pm)$-PPCC, BD 1047) as well as clinically used drugs which exert affinity to sigma receptors (e.g. haloperidol, fluvoxamine, sertraline, amitriptyline) have played crucial role in the research. Based on their different binding profiles, sigma receptors were classified as 
follows (Quirion et al. 1992): sigma 1 receptors exert high affinity to dextromethorphan, (+)-pentazocine, $(+)-N A N M$, and carbetapentane; sigma 2 receptors bind these compounds with low affinity. Haloperidol and DTG, two mostly used sigma ligands in 1980s and 1990s, show affinity for both sigma subtypes (Kushner and Zukin 1994). Moreover, sigma subtypes exert different stereoselectivity for benzomorphans: sigma 1 receptor exhibits higher affinity for dextrorotatory benzomorphans and, in contrast, sigma 2 receptor exhibits equal or higher affinity for the levorotatory benzomorphans (Hellewell and Bowen 1990).

\section{Sigma 1 receptor-molecular structure}

Research on cellular localization(s) and function(s) of sigma receptors was significantly facilitated by description of molecular structure of the sigma 1 receptor. The sigma 1 receptor was first purified and cloned from guinea pig liver in 1996 (Hanner et al. 1996). The amino acid sequence was structurally unrelated to then known mammalian proteins (Hanner et al. 1996). Subsequently, the receptor was cloned from various tissues, both animal and human ones (Kekuda et al. 1996, Seth, Leibach, and Ganapathy 1997, Prasad et al. 1998, Seth et al. 1998, Mei and Pasternak 2001). Mei and Pasternak (2001) reported that predicted structure of rat sigma 1 receptor is highly homologous with murine (93.3\%), guinea pig (93.7\%) and human (96.0\%) sigma 1 receptor. Many structural models of the receptor were postulated ( $\mathrm{Su}$ and Hayashi 2003, Laurini et al. 2011, Schmidt et al. 2016, Laurini et al. 2017). Most of them described sigma 1 receptor as membrane receptor with two transmembrane domains (Laurini et al. 2017). It was reported that ligand-binding region of sigma 1 receptor is similar to an active site of cupin family proteins, oligomeric bacterial and fungal enzymes, and plant seed storage proteins (Hanner et al. 1996, Schmidt et al. 2016). One of them is the yeast sterol C8-C7 isomerase, enzyme essential for ergosterol synthesis and cell proliferation (Moebius et al. 1997). In spite of structural homology, sigma 1 receptor binding region exerts no enzymatic activity. In addition, Mishra and co-workers reported, that sigma 1 receptor can be found either in monomeric or oligomeric forms in living cells in the presence and/or absence of various ligands (Mishra et al. 2015).

Recently, evidence of the full crystal structure was reported (Schmidt et al. 2016). According to X-ray data, the solid-state structure of the sigma 1 receptor reveals a trimeric organization with a single transmembrane domain for each protomer (Schmidt et al. 2016). The cytosolic domain of each of the three protomers contains a $\beta$-barrel fold with the ligandbinding region at its center. Such structure is substantially different from the two-transmembrane domain model proposed on the basis of biochemical, molecular, in silico, and NMR data (Laurini et al. 2011, Laurini et al. 2017). As Laurini et al. (2017) postulated, differences may arise from various factors, such as structure determination methods and experimental conditions used. Moreover, the protein may adopt different structures under solid and solution states. More studies are needed to prove structural details of sigma 1 receptor protein.

\section{Sigma 1 receptor - ligands}

The classification of sigma ligands as agonists and antagonists is mainly based on animal studies. Agonists are defined as ligands that induce hyperlocomotion or other physiological responses through binding to sigma receptor, while antagonists are ligands that block or blunt this response (Martin et al. 1976, Schmidt et al. 2016). Various endogenous substances, such as progesterone, dihydroepiandrosterone, sphingosine and its derivatives, and $N, N$-dimethyltryptamine, exert certain affinity to sigma 1 receptor (Patterson et al. 1994). Although these substances can bind to sigma 1 receptor under experimental conditions, up to now none of them has been reported to act as endogenous sigma 1 ligand. Nine years ago, Fontanilla et al. (2009) indicated $N, N$-dimethyltryptamine as endogenous sigma 1 regulator. However, relevant doubts were recently cast on this suggestion (Nichols 2018) and the endogenous ligand still seems to be undiscovered. The precise structure of the ligand-binding region may shed light on this problem.

\section{Sigma 1 receptor-localization and function}

The sigma 1 receptor is involved in a wide range of physiological functions and pathophysiological processes in nervous system, such as neurodegenerative diseases, neuropathic pain, depression and cocaine addiction (Su et al. 2016). It has been localized in several regions of the central nervous system as well as in peripheral nervous system and numerous non-neural tissues. According to immunohistochemical studies in rat, high density of sigma 1 receptor was found in olfactory bulb, several hypothalamic nuclei, septum, central grey, certain motor nuclei of the hindbrain, and dorsal horn of spinal cord (Alonso et al. 2000, Bouchard and Quirion 
1997). Among non-neural tissues, high density of the sigma 1 receptor was found in the immune, endocrine and reproductive systems and in the digestive tract (Wolfe et al. 1989, Hellewell et al. 1994), as well as in the heart (Ela et al. 1994, Novakova et al. 1995).

Intracellular localization of sigma 1 receptor has been intensively studied. Various localizations were reported among different cell types and various stages of cell differentiation. The primary region, where sigma 1 receptor is located, is endoplasmic reticulum membrane associated with mitochondria (Hayashi and $\mathrm{Su} 2007$ ). Sigma 1 receptor acts here as molecular chaperone. By interaction with various proteins, it promotes survival of the cell by regulation of calcium signaling, enhancing the endoplasmic reticulum signaling to nucleus and attenuating response to oxidative stress (Boehning et al. 2003, Mori et al. 2013, Su et al. 2016). Nevertheless, translocation of sigma 1 receptor was reported repeatedly after sigma ligand stimulation or cellular stress (Hayashi and Su 2007, Mavlyutov and Ruoho 2007). Hayashi and $\mathrm{Su}$ proved translocation from lipid-enriched sites of the endoplasmic reticulum to the endoplasmic reticulumassociated reticular network upon stimulation by psychoactive drugs in NG108-15 cells (Hayashi and $\mathrm{Su}$ 2003). Johannessen and co-workers reported inhibition of sodium voltage-gated channel $\mathrm{Na}_{\mathrm{V}} 1.5$ by sigma 1 ligands in mouse cardiomyocytes (Johannessen et al. 2009). Voltage-gated sodium channels are resident plasma membrane channels and such inhibition suggested the co-operation of sodium channel with sigma 1 receptor on plasma membrane. Translocation to plasma membrane was proved repeatedly in neuronal tissue and was previously reviewed ( $\mathrm{Su}$ et al. 2010). Recently, translocation to nuclear envelope was reported after haloperidol treatment in differentiated NG-108 cells (Kubickova et al. 2018). Mavlyutov and co-authors determined precise intracellular localization of sigma 1 receptor in retinal neurons using electron microscopy (Mavlyutov et al. 2015). In photoreceptor cells, predominal presence of sigma 1 receptor in the nuclear envelope and in the subsurface endoplasmic reticulum cisternae was found (Mavlyutov et al. 2015). Authors suggested mechanism of sigma 1 receptor action possibly different from that determined in other cell types.

It is generally accepted that the sigma 1 receptor works as a ubiquitous pluripotent modulator in the mammalian cells and interacts with many proteins (e.g. receptors, ion channels, enzymes, chromatin-remodeling factors) in various intracellular locations ( $\mathrm{Su}$ et al. 2016).
However, different methodological approaches were employed in abovementioned studies. Therefore, many questions concerning sigma 1 receptor localization and functioning remain unanswered.

\section{Sigma 1 receptor in the heart}

Contrary to other tissues, the first report on the presence of sigma receptors in the heart muscle was focused on sigma 2 type (Dumont and Lemaire 1991). Based on specific binding activity of the prototypic sigma receptor ligand [3H]-DTG, Dumont and Lemaire concluded that sigma 2 receptors are present on the rat heart membrane preparations. As reported later, the majority of sigma receptors $(75 \%)$ in the rat heart is represented by sigma 1 receptors (Novakova et al. 1995). Therefore, numerous studies were focused on cardiac sigma 1 receptor in various experimental models.

\section{Sigma 1 receptor gene and regulation of its expression}

Sigma 1 receptor is coded by SIGMAR1 gene (GeneCards ${ }^{\circledR}$ : Human Gene Database). In mouse, it was recognized on chromosome 4 , in rat on chromosome 5 . In human, the gene is located on the shorter arm of chromosome 9. Polymorphisms and mutations in SIGMAR1 in human population were identified and their association with neurodegenerative and psychiatric diseases have been reported (Luty et al. 2010, Al-Saif, Al-Mohanna, and Bohlega 2011, Huang et al. 2011, Mandelli et al. 2017). Up today, there is no evidence of association of SIGMAR1 variants with cardiovascular disorders.

In human genome, more than 20 regulatory regions for SIGMAR1 gene were identified. Only a few regulating mechanisms of SIGMAR1 expression are clear yet. Nevertheless, numerous factors, which affect expression of sigma 1 receptor in heart, have been reported in various models. Novakova et al. (2007) found that sigma 1 receptors in rat heart are upregulated by aging as well as by various stress factors, such as immobilization and cold environment. In mice, upregulation was caused by hypoxia (Novakova et al. 2007). Sigma 1 receptors are upregulated also by longterm exposure to prototypic sigma ligand haloperidol in heart of rat (Novakova et al. 2010) and guinea pig (Stracina et al. 2015). Specific regulatory mechanisms of these phenomena have not been identified yet.

The first evidence of a specific transcriptional factor regulating sigma 1 expression was brought by 
Mitsuda and coworkers (Mitsuda et al. 2011). They reported that sigma 1 receptor can be upregulated by escalated endoplasmic reticulum stress by the PERK/ATF4 pathway. Activation of the pathway leads to amelioration of cell death signaling. Recently, key role of miRNA-297 in sigma 1 expression regulation during cardiomyocyte hypertrophy was reported (Bao et al. 2017). Regulation by other microRNAs has been also proposed (Su et al. 2016).

\section{Cellular function of sigma 1 receptor}

Sigma 1 receptors are expressed in atrial and ventricular cardiomyocytes of both rat and guinea pig (Novakova et al. 2010, Stracina et al. 2015) as well as in intracardiac neurons (Zhang and Cuevas 2005). Function of the sigma 1 receptor, as a molecular chaperone, is based on interaction with various proteins. Due to intensive research of sigma receptors in neuronal system, a lot of protein-protein interactions have been identified in neuronal models (Pabba 2013, Su et al. 2016). Based on direct or indirect evidence, many of them can be applied in cardiomyocytes, too; in others, we can presume that the interactions are analogous. Key protein interactions are shown in Figure 1.

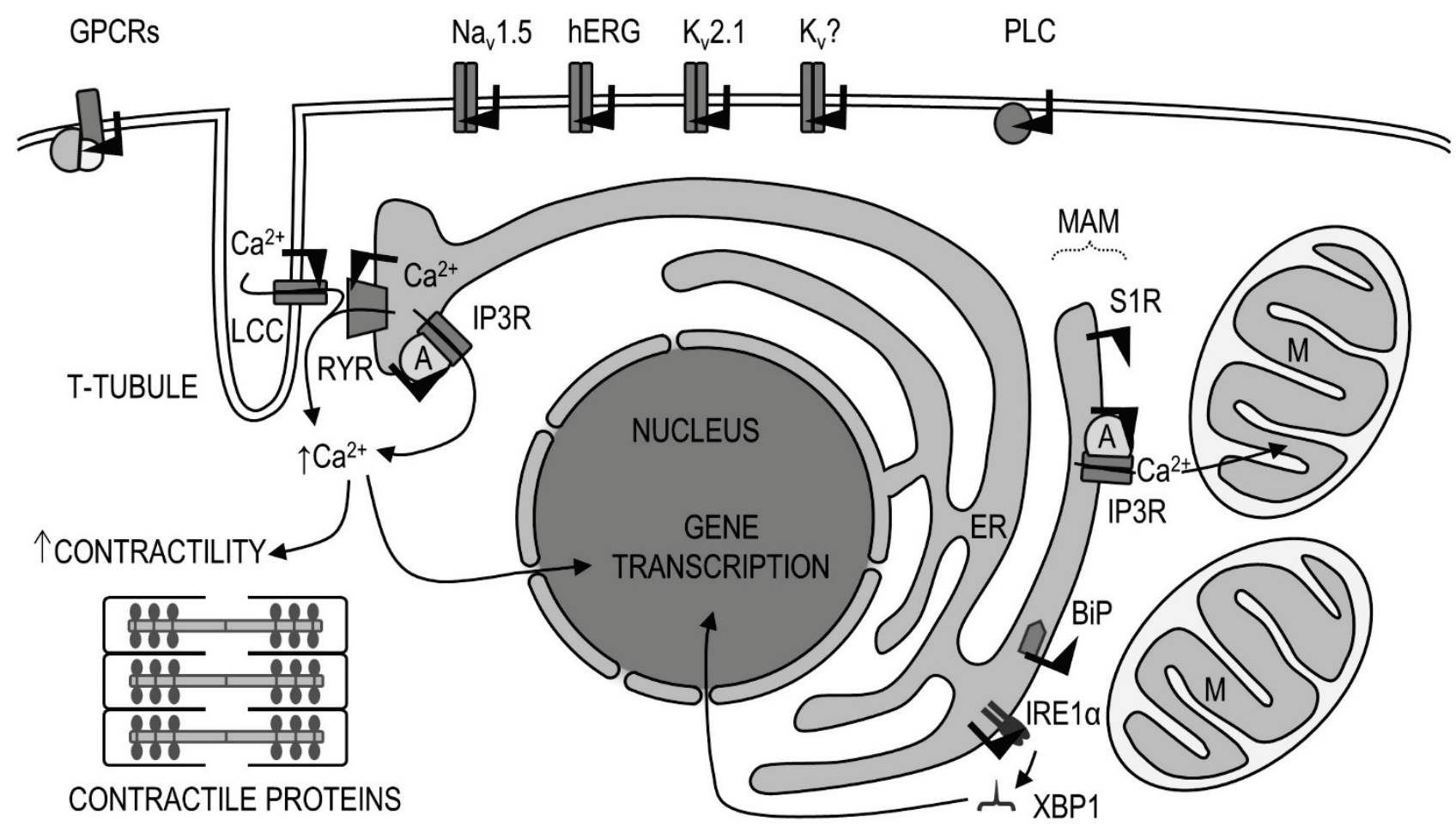

Fig. 1. The Sigma 1 Receptor Protein Interactions in Cardiomyocyte. Sigma 1 receptors are represented by black flags. They are primarily located on mitochondrion-associated endoplasmic reticulum membrane (MAM). Only key interactions related to the text are presented. All presented interactions were determined experimentally. For more information see corresponding chapters in the text. A - ankyrin B; BiP - binding immunoglobulin protein; $\mathrm{Ca}^{2+}$ - calcium ions; $\mathrm{ER}$ - endoplasmic reticulum; GPCRs - G protein-coupled receptors; hERG - human ether-a-go-go-related gene potassium voltage-gated channel; IP3R - inositol 1,4,5-trisphosphate receptor; IRE1 $\mathrm{a}$ - inositol requiring protein $1 \mathrm{a} ; \mathrm{K}_{\mathrm{v}}$ ? - potassium voltage-gated channel ensuring transient outward potassium current; $\mathrm{K}_{\mathrm{v}} 2.1$ $\mathrm{K}_{\mathrm{v}} 2.1$ potassium voltage-gated channel; LCC - L-type calcium voltage-gated channel; $\mathrm{M}$ - mitochondria; MAM - mitochondrionassociated endoplasmic reticulum membrane; $\mathrm{Na}_{\mathrm{v}} 1.5$ - Nav1.5 sodium voltage-gated channel; PLC - phospholipase C; RYR - ryanodine receptor; S1R - sigma 1 receptor in trimeric form; XBP1 - spliced X-box binding protein 1.

Interaction with endoplasmic reticulum membrane proteins - a modulation of calcium handling and dealing with endoplasmic reticulum stress

The endoplasmic reticulum plays an essential role in calcium handling, protein synthesis and folding, and lipid synthesis in the cell (Glembotski 2012). The endoplasmic reticulum calcium pool is important for contraction of cardiomyocyte as well as for signaling within the cell. The first studies about effect of sigma ligands on the cardiomyocytes reported increased calcium influx which led to increased contractility (Ela et al. 1994, Novakova et al. 1995). It was suggested that sigma 1 receptor directly affects calcium channels or modulates potassium channels on plasma membrane (Ela et al. 1994). Subsequent study uncovered that sigma 1 ligands increase inositol 1,4,5-trisphosphate (IP3) 
production in cardiomyocytes and observed increase of contractility depends on calcium stores in endoplasmic reticulum (Novakova et al. 1998). IP3 activates its receptor, a transmembrane glycoprotein complex primarily located on endoplasmic reticulum membrane. After the activation, IP3 receptor releases calcium from endoplasmic reticulum (Fig. 1). Three types of IP3 receptors affect cardiac function to various extent (Kockskämper et al. 2008). IP3 receptors type 1 and 2 represent important intracellular calcium channels in cardiomyocytes (Garcia and Boehning 2017). An overexpression of IP3 receptor types 1 and 2 were reported in rat and guinea pig heart after long-term exposure to sigma ligand haloperidol (Novakova et al. 2010, Stracina et al. 2015).

The chaperone activity of sigma 1 receptor on IP3 receptor, first described on Chinese hamster ovary cells with transfected receptors (Hayashi and $\mathrm{Su}$ 2007), was proven in cardiomyocytes (Tagashira et al. 2013). Besides IP3 receptors, an interaction with other important intracellular calcium channel, ryanodine receptor type 2, was discovered in cardiomyocytes. Tagashira et al. showed that sigma 1 receptors are associated both with ryanodine receptors type 2 and IP3 receptors type 2 in cardiomyocyte endoplasmic reticulum membrane (Tagashira et al. 2013). Sigma ligand pentazocine suppressed ryanodine receptor mediated calcium release from endoplasmic reticulum, which consequently led to decreased contraction force. Sigma 1 receptor stimulation also promotes mitochondrial calcium transport through IP3 receptor type 2 (Fig. 1) and in turn ATP production (Tagashira et al. 2013).

Cross-talk between endoplasmic reticulum and mitochondrion is important for maintaining homeostasis in both organelles. Impairment of endoplasmic reticulum luminal homoeostasis leads to misfolding or unfolding of proteins. An accumulation of unfolded proteins is known as endoplasmic reticulum stress (Glembotski 2007). Protein synthesis and folding are controlled by endoplasmic reticulum protein quality control mechanisms and accumulation of unfolded proteins is sensed by endoplasmic reticulum stress sensors: inositol requiring protein $1 \alpha$ (IRE1 $\alpha)$, protein kinase RNA-like ER kinase (PERK) and transcriptional factor 6 (ATF6) (Liu et al. 2016). In these processes, endoplasmic reticulum resident proteins take important part. Endoplasmic reticulum stress activates a complex signaling pathway to deal with the misfolded and unfolded proteins, which is referred as the unfolded protein response. The rate of general translation is reduced and the expression of endoplasmic reticulum resident protein chaperones and protein foldases is increased to restore homeostasis. However, if the unfolded protein response is unsuccessful, endoplasmic reticulum stress causes cell dysfunction and apoptotic pathways are activated (Biala and Kirshenbaum 2014). Recently, potential function of sigma 1 receptor in regulating normal mitochondrial organization and size in the heart was reported in sigma 1 receptor knockout mouse model (Abdullah et al. 2018).

Sigma 1 receptor, as the endoplasmic reticulum resident protein, has been found to promote cellular survival by regulating specific endoplasmic reticulum stress sensors at the mitochondria-associated membrane region under endoplasmic reticulum stress in various cellular models (Hayashi and $\mathrm{Su}$ 2001, Hayashi and Su 2007, Wu and Bowen 2008, Mitsuda et al. 2011, Mori et al. 2013). Reported sigma 1 receptor dependent protective signaling pathways significantly differ in various cell types. Recently, sigma 1 receptor was reported as an essential component of the unfolded protein response pathway eliciting cellular protection in cardiomyocytes (Alam et al. 2017). Alam et al. (2017) described that sigma 1 receptor regulates C/EBPhomologous protein expression in association with activation of the inositol requiring kinase $1 \alpha$ and spliced X-box binding protein 1 (IRE1 $\alpha / \mathrm{XBP} 1$ ) pathway (Fig. 1). The IRE1 $\alpha / \mathrm{XBP} 1$ pathway is the most conserved branch of the unfolded protein response in mammals and is important for cardiomyocyte viability and contractile function (Wang et al. 2014).

Numerous implications may be proposed from currently known sigma 1 receptor functions on endoplasmic reticulum membrane. However, there are a lot of unanswered questions. The answers may bring some new insights into endoplasmic reticulum and mitochondrion coordination and consequently into pathophysiology of many heart diseases.

Interaction with voltage-gated ion channels a modulation of action potential of cardiomyocytes

Generally, three main groups of voltage-gated ion channels are present in working cardiomyocytes: sodium voltage-gated channels conduct sodium current, responsible for membrane depolarization; calcium voltage-gated channels conduct calcium current, which contributes to the plateau phase of action potential; and potassium voltage-gated channels conducting potassium 
currents, which ensures returning the depolarized membrane to a resting state. There is direct or indirect evidence, that sigma 1 receptor modulates all main ion currents in cardiomyocytes.

Inhibitory effect of haloperidol on activated sodium current was reported in human atrial cardiomyocytes and in rat ventricular cardiomyocytes (Crumb et al. 2006, Tarabova et al. 2009). Johannessen et al. (2009) described modulation of $\mathrm{Na}_{\mathrm{v}} 1.5$ channels by sigma 1 receptors in. They showed that level of $\mathrm{Na}_{\mathrm{v}} 1.5$ channel inhibition by selective sigma 1 ligands depends on number of sigma 1 receptors on plasma membrane, however non-specific ligands, such as haloperidol, inhibit $\mathrm{Na}_{\mathrm{v}} 1.5$ channel also on cells with no sigma 1 receptors. As a possible explanation of above result, direct effect of non-selective ligands on ion channels as well as modulation via sigma 2 receptors were proposed (Johannessen et al. 2009). Modulation of $\mathrm{Na}_{\mathrm{v}} 1.5$ channels by sigma ligands can be inhibited by progesterone (Johannessen et al. 2011). The sigma 1 receptor has been reported to modulate sodium channels $\mathrm{Na}_{\mathrm{v}} 1.2, \mathrm{Na}_{\mathrm{v}} 1.4$ and $\mathrm{Na}_{\mathrm{v}} 1.5$ also in non-cardiac cells (Balasuriya et al. 2012, Gao et al. 2012).

Effect on calcium current was reported by Ela et al. (1994) who described increased influx of calcium into the neonatal rat cardiomyocyte after sigma 1 receptor stimulation. Twelve years after, sigma 1 ligand haloperidol was reported as mild to moderate blocker of the L-type calcium channel (Tarabova et al. 2009). It was proven that inhibitory effect is independent on channel splice variant (cardiac or vascular). The modulation of calcium current by sigma 1 receptor was also reported in non-cardiac cells (Brent et al. 1996, Tchedre et al. 2008). In retinal ganglion cells, direct interaction of L-type calcium channel with sigma 1 receptor was proven by coimmunoprecipitation assay (Tchedre et al. 2008).

Potassium channels are the most diverse group of voltage-gated channels (Perney and Kaczmarek 1991). Potassium repolarizing current on cardiomyocytes consists of several components. In rat ventricular cardiomyocytes, haloperidol was reported as an effective inhibitor of one of them (Bebarova et al. 2006). Haloperidol inhibits transient outward potassium current $\left(\mathrm{I}_{\mathrm{to}}\right)$ and significantly decelerates its recovery. Based on whole-cell patch-clamp recordings, direct modulation of potassium channels by sigma 1 receptor was suggested in isolated intracardial neurons (Zhang and Cuevas 2005). In dose-dependent manner, sigma ligands reversibly block delayed outward rectifying potassium channels, increase conductance of calcium-sensitive potassium channels and inhibit M-current.

The relationship between the sigma 1 receptor and hERG (human ether-a-go-go-related gene) potassium channel has been studied intensively. The hERG channels are responsible for the rapid component of delayed rectifier current $\mathrm{I}_{\mathrm{Kr}}$. Haloperidol was reported to block the hERG channels expressed in Xenopus oocytes (Suessbrich et al. 1997) and in human embryonic kidney cells (HEK 293) (Martin et al. 2004, Katchman et al. 2006). In the leukemic K562 cell line, the regulating function of sigma 1 receptors on $\mathrm{hERG}$ expression was clarified (Crottès et al. 2011). The sigma 1 receptor modulates the hERG current density in the presence of sigma ligands. However, the direct interaction between sigma 1 receptor and hERG in the plasma membrane is not sigma 1 ligand dependent, it is reduced by cholesterol depletion. Coimmunoprecipitation study proposed that sigma 1 receptors located in lipid rafts (Balasuriya et al. 2014) potentiate the hERG subunit's translocation from endoplasmic reticulum to Golgi apparatus (Crottès et al. 2011). Altogether, sigma 1 receptor binds to $\mathrm{hERG}$ channel in endoplasmic reticulum and facilitates $\mathrm{hERG}$ maturation and trafficking. Su et al. (2016) suggested that sigma 1 receptor might exert chaperoning activities in endoplasmic reticulum to facilitate proper protein sorting to their final destinations. However, such relationship of sigma 1 receptor with other proteins (except of hERG) has not been proven yet.

The effect of many clinically used sigma ligands on cardiac action potential and electrocardiogram parameters was observed in various experimental models. Besides used experimental model and tested ligand, the studies usually vary in dosage and route of administration. In clinical studies, patients are usually treated by more than one drug and drugs interactions may make interpretation of obtained results more difficult. Moreover, sigma 1 ligands may affect various ion channels as well as various receptor systems in the same time. Also, direct action of the ligand on ion channel should be taken in consideration. Potential receptorindependent inhibition of the $\mathrm{K}_{\mathrm{v}} 2.1$ channel by sigma ligands was recently reported (Liu et al. 2017). In sum, the reported effects of sigma 1 ligands on ion channels seem to be inconsistent and most of the specific mechanisms of sigma 1 receptor interactions with ion channels are unclear. 
Other protein interactions - another pieces of incomplete mosaic

It may be expected that sigma 1 receptor interacts - besides abovementioned - with numerous other proteins in cardiomyocytes. Among others, interaction with opioid receptors, NMDA receptors and dopamine receptors has been reported in neuronal models (Mei and Pasternak 2002, Navarro et al. 2010, Balasuriya et al. 2013). However, action of these receptor systems in the heart is not fully understood and only indirect evidence of interaction with cardiac sigma 1 receptor has been reported and the mosaic of cardiac sigma 1 receptor actions stays incomplete.

\section{Role of sigma 1 receptor in pathophysiology of cardiovascular diseases}

Our current knowledge about physiological functions of cardiac sigma 1 receptors are still incomplete and their pathophysiological roles are largely unknown. Only a few studies have been focused on the expression and function of sigma 1 receptors in cardiovascular disorders. Recently, significant roles of sigma 1 receptors in cardiac hypertrophy and heart failure have been proposed. Moreover, many of clinically used sigma 1 ligands exert cardiovascular side effects.

\section{Cardiac hypertrophy and heart failure}

It is well known, that endoplasmic reticulum stress is important agent in pathophysiology of many cardiovascular diseases, such as hypertension, atherosclerosis, myocardial infarction, and cardiac hypertrophy which ultimately result in heart failure (Liu et al. 2016). Cardiac hypertrophy is caused by pressure/ volume overload or overactivation of neurohumoral systems, such as the renin-angiotensin-aldosterone system. It is initiated as an adaptive response, but if the process is uncontrolled and prolonged, it may lead to heart failure and eventually to death (Shimizu and Minamino 2016). Moreover, increased myocardium mass may lead to decreased tolerance of heart to ischemia (Hlaváčová et al. 2017).

As discussed above, activation of sigma 1 receptors leads to amelioration of endoplasmic reticulum stress. Sigma 1 ligands may therefore protect the heart from hypertrophy. Cardioprotective role of the sigma 1 receptors was also reported after stimulation by dehydroepiandrosterone in ovariectomized rats, which leads to activation of the Akt-eNOS pathway (Bhuiyan and Fukunaga 2009). On the other hand, inhibition of Akt pathway by endogenous oxidative stress may lead to autophagy of cardiomyocytes (Wang et al. 2018). In addition, exposure to sigma 1 antagonist haloperidol aggravates hypertrophy by impairment of mitochondrial calcium signaling in cardiomyocytes (Shinoda et al. 2016) and stimulation of sigma 1 receptors restores abnormal mitochondrial calcium mobilization and ATP production (Tagashira et al. 2013, Tagashira et al. 2014). Recently, miR-297 was proposed as a novel regulator of sigma 1 receptor in cardiomyocyte hypertrophy (Bao et al. 2017). Up-regulation of miR-297 increases the activation of XBP1 and ATF4 pathways via targeting sigma 1 receptor, which promotes cardiomyocyte hypertrophy. However, the precise mechanism by which sigma 1 receptor induces this action has not been described yet.

Cardiovascular adverse effects of clinically used sigma 1 ligands

Many sigma 1 ligands are used in clinical practice for treatment of various diseases (Table 1). Some of them exert cardiovascular side effects. The spectrum of the effects varies from frequent mild blood pressure change (hypotension or hypertension) to sporadic lifethreating ventricular arrhythmias, which may lead to sudden cardiac death.

It is out of scope of this review to pose all the sigma 1 ligands, in which cardiovascular adverse effects have been reported. Among all, cardiovascular side effects of the prototypic sigma 1 ligand haloperidol are the most controversial: haloperidol-induced QT prolongation is comparable to other antipsychotics; however, haloperidol treatment significantly increases a risk of ventricular arrhythmias and sudden cardiac death (Leonard et al. 2013, Leucht et al. 2013, Wu et al. 2015). In animal studies, reported effects of haloperidol seem to be consistent. Haloperidol provokes QT interval prolongation and cardiac arrhythmias, such as torsades de pointe. In isolated rat hearts, exposure to haloperidol leads to premature ventricular contractions. Incidence of arrhythmias was significantly lowered after repeated haloperidol administration, which suggest desensitization of sigma 1 receptor (Fialova et al. 2009). In rats, increased expression of sigma 1 receptor was detected in all heart chambers after long-term haloperidol administration (Novakova et al. 2010). QT prolongation and increase of sigma 1 receptor expression in cardiac atria were reported in guinea pigs after long-term haloperidol administration (Stracina et al. 2015). Expressions of IP3 receptor type 1 and 2 were also 
increased in the atria only. Acute haloperidol exposure causes slowing of intraventricular conduction and lengthening of repolarization in anesthetized guinea pigs (Mortl et al. 2003).

Antipsychotic drug haloperidol is a nonselective ligand, which acts as a sigma 1 receptor antagonist as well as a dopamine D2 and D3 receptor antagonist (Hayashi and
$\mathrm{Su}$ 2004). Haloperidol can also interact with other receptor systems. Moreover, haloperidol exerts significant cytotoxicity (Raudenska et al. 2013). Altogether with considerable variability in experimental methods, dosage and route of administration in the studies, it is difficult to propose a role of sigma 1 receptors in the observed cardiovascular effects of haloperidol.

Table 1. Clinically used drugs with affinity to sigma 1 receptor.

\begin{tabular}{|c|c|c|}
\hline Drug category & Sigma 1 ligand & References \\
\hline Analgesics & Pentazocine & Zhang and Cuevas 2005 \\
\hline Anesthetics & Ketamine & Robson et al. 2012 \\
\hline $\begin{array}{l}\text { Anticonvulsants and } \\
\text { Antiepileptic Agents }\end{array}$ & Lamotrigine, Phenytoin & Cobos et al. 2005 \\
\hline Antidepressants & $\begin{array}{l}\text { Citalopram, Escitalopram, Fluoxetine, } \\
\text { Fluvoxamine, Opipramol, Sertraline }\end{array}$ & $\begin{array}{c}\text { Hashimoto 2009, Albayrak and } \\
\text { Hashimoto } 2017\end{array}$ \\
\hline Antidiarrheals & Loperamide & Sánchez-Fernández et al. 2014 \\
\hline $\begin{array}{l}\text { Anti-Parkinson and Anti- } \\
\text { Dementia Drugs }\end{array}$ & Amantadine, Donepezil, Memantine & $\begin{array}{c}\text { Peeters et al. 2004, Albayrak and } \\
\text { Hashimoto } 2017\end{array}$ \\
\hline Antipsychotics & $\begin{array}{c}\text { Fluphenazine, Gevotroline, Haloperidol, } \\
\text { Nemonapride, Perphenazine, } \\
\text { Remoxipride, Risperidone, } \\
\text { Trifluoperazine }\end{array}$ & Schuster et al. 1995 \\
\hline Antitussive Agents & $\begin{array}{c}\text { Dextromethorphan, Dimemorphan, } \\
\text { Pentoxyverine, }\end{array}$ & Nguyen et al. 2014 \\
\hline Psychostimulants & Methylphenidate & Zhang et al. 2012 \\
\hline Psychoactive Substances & $\begin{array}{c}\text { Cocaine, Ibogaine, Methamphetamine, } \\
\text { Phencyclidine }\end{array}$ & Navarro et al. 2013, Chao et al. 2017 \\
\hline
\end{tabular}

Sigma 1 receptor as a cross-link between mental and cardiovascular disorders

Epidemiological studies have demonstrated a close relationship between depression and cardiovascular diseases (Trebatická et al. 2017). Cardiovascular diseases can lead to severe depression (Gottlieb et al. 2004). Among cardiovascular diseases, the strongest association with depression has been reported in ischemic heart disease and after myocardial infarction (Schleifer et al. 1989). Inversely, depression can lead to significant increase in the risk of developing heart failure and is independently associated with increased cardiovascular morbidity and mortality (Rumsfeld et al. 2003).

In 2012, Ito et al. suggested that decreased brain sigma 1 receptor expression contributes to the relationship between heart failure and depression in a mouse model of pressure overload. As a part of link between depression and cardiovascular diseases, brainderived neurotrophic factor (BDNF) was discussed as an important agent. It was shown that the BDNF-TrkB pathway plays a role in the pathophysiology of cardiovascular diseases as well as depression and interaction between sigma 1 receptor and the BDNFTrkB pathway was discussed (Hashimoto 2013). Bhuyian et al. (2013) proposed a hypothesis of sigma 1 receptor mediated protective mechanism in cardiomyocyte, which may explain protective effect of selective serotonin uptake inhibitors on heart failure progression. In mouse model of myocardial infarction, decreased expression of brain sigma 1 receptor was reported (Ito et al. 2013). Brain sigma 1 receptor stimulation improves mental 
disorder and cardiac function in mice after myocardial infarction. Recently, it was reported that heart failureinduced depression in mice is mediated by corticosteroids through reduced sigma 1 receptor expression in the brain (Shinoda et al. 2016).

Not only depression can affect cardiovascular functions. QT interval prolongation was reported in drug-free patients suffering from schizophrenia (Fujii et al. 2014). Authors suggested a role of potassium channels inhibition in both disorders. QT prolongation was also found in rat neurodevelopmental model of schizophrenia (Stracina et al. 2016). As the sigma 1 receptors are ubiquitous molecular regulators, their contribution to link between schizophrenia and QT prolongation may be based on their pluripotent chaperone activity. However, this issue needs furthers investigation.

\section{Neurodegenerative diseases}

Association of sigma 1 receptor with various neurodegenerative diseases (e.g. amyotrophic lateral sclerosis, Huntington's disease, Alzheimer disease, Parkinson disease) was intensively studied (Cai et al. 2017). During last decade, disease-causing mutations in sigma 1 receptor gene (SIGMAR1) were associated with juvenile amyotrophic lateral sclerosis (ALS) and juvenile distal hereditary motor neuropathy in humans (Al-Saif et al. 2011, Li et al. 2015). As Mavlyutov and co-authors reviewed, sigma 1 receptor knockout mouse did not develop ALS (Mavlyutov et al. 2015). However, sigma 1 receptor knockout in mouse SOD-1 model of ALS led to a faster onset of disease and decreased longevity (Mavlyutov et al. 2013). Recently, sensory and autonomic nervous system dysfunction in ALS was described (Nolano et al. 2017, Vucic 2017). Impaired neuronal regulation of cardiac function in ALS patients was reported previously (Dalla Vecchia et al. 2015). It is not clear, if such impaired regulation may lead to cardiovascular disease progression. In Huntington's disease, association of neurodegeneration and cardiac malfunction was proved (Critchley et al. 2018). However, possible role of sigma 1 receptor has not been studied in such consequences yet. The proper molecular mechanisms of neuro-cardio link in neurodegenerative diseases need to be uncovered.

\section{Sigma 2 receptor}

Sigma 2 receptor is one of the most poorly understood proteins in cell biology today. While sigma 2 receptor has not been cloned yet, its exact molecular structure is not known so far. It was suggested that the sigma 2 receptor is identical with the progesterone receptor membrane component 1 (Xu et al. 2011). However, Chu et al. (2015) reported that both these proteins are different binding sites derived from independent genes. According to binding studies, high density of sigma 2 receptors are present in cerebellum, motor cortex, substantia nigra, hippocampus (Bouchard and Quirion 1997), in lungs, liver, kidneys (Hellewell et al. 1994), and in cells with high proliferation rate, such as tumor cells (Xu et al. 2011). Because of overexpression in many types of tumors, sigma 2 receptors have been intensively researched in the field of tumor biology, cancer diagnostics and treatment (van Waarde et al. 2015). Radiolabeled sigma ligands have been developed and are used for diagnostic imaging using positron emission tomography and single photon emission computed tomography. Sigma 2 receptors have been also explored as a possible target for anticancer drug delivery. Moreover, cytotoxic and anticancer effects of sigma 2 ligands have been reported (Zeng et al. 2012). Nevertheless, specific functions of sigma 2 receptors in tumor as well as other cells stay unclear.

According to our best knowledge, there is only one relevant study dealing with sigma 2 receptor action in the heart. Monassier and co-workers reported that sigma 2 agonist inhibits inwardly rectifying potassium channels in the heart (Monassier et al. 2007).

Many studies have reported close and overlapping pharmacological and biochemical properties of sigma 1 and sigma 2 receptors. Therefore, sigma 2 receptors might also act as a molecular chaperones ( $\mathrm{Su}$ et al. 2016). However, proper description of role of sigma 2 receptor needs further investigation.

\section{Future perspectives}

Although numerous studies have been focused on the effects of cardiac sigma 1 receptors, many pieces of the mosaic of their functions are missing. A major step forward to better understanding of cardiac sigma 1 receptor function would be the identification of the endogenous ligand(s) responsible for the action of sigma 1 receptors under physiological as well as pathological conditions. This step might be promoted by precise structural model of the receptor. Knowledge of the crystal protein structure opens new possibilities in design and preparation of novel highly specific sigma 1 
ligands. Such ligands will help in research of new therapeutic strategies. In the heart disorders associated with protein misfolding, sigma 1 receptor-dependent activation of IRE1 $\alpha$-XBP1s pathway may preserve myocyte viability and contractile function (Alam et al. 2017). In cardiac hypertrophy treatment, rescuing the decreased expression of sigma 1 receptor through miR-297 inhibition may be beneficial (Bao et al. 2017). And other perspectives will appear as the further investigation will shed new light onto the topic.

\section{Conflict of Interest}

There is no conflict of interest.

\section{Acknowledgements}

This review was written at Masaryk University as part of the project "Kardiovaskulární systém naprríč obory - od molekulární diagnostiky po klinická vyšetření" number MUNI/A/1157/2017 with the support of the Specific University Research Grant, as provided by the Ministry of Education, Youth and Sports of the Czech Republic in the year 2018 .

\section{References}

ABDULLAH CS, ALAM S, AISHWARYA R, MIRIYALA S, PANCHATCHARAM M, BHUIYAN MAN, PERETIK JM, ORR AW, JAMES J, OSINSKA H, ROBBINS J, LORENZ JN, BHUIYAN MS: Cardiac dysfunction in the sigma 1 receptor knockout mouse associated with impaired mitochondrial dynamics and bioenergetics. $J$ Am Heart Assoc 7: e009775, 2018.

AL-SAIF A, AL-MOHANNA F, BOHLEGA S: A mutation in sigma-1 receptor causes juvenile amyotrophic lateral sclerosis. Ann Neurol 70: 913-919, 2011.

ALAM S, ABDULLAH CS, AISHWARYA R, ORR AW, TRAYLOR J, MIRIYALA S, PANCHATCHARAM M, PATTILLO CB, BHUIYAN MS: Sigmar1 regulates endoplasmic reticulum stress-induced C/EBP-homologous protein expression in cardiomyocytes. Biosci Rep 37: pii: BSR20170898, 2017.

ALBAYRAK Y, HASHIMOTO K: Sigma-1 receptor agonists and their clinical implications in neuropsychiatric disorders. Adv Exp Med Biol 964: 153-161, 2017.

ALONSO G, PHAN V, GUILLEMAIN I, SAUNIER M, LEGRAND A, ANOAL M, MAURICE T: Immunocytochemical localization of the sigma(1) receptor in the adult rat central nervous system. Neuroscience 97: 155-170, 2000.

BALASURIYA D, STEWART AP, CROTTÈS D, BORGESE F, SORIANI O, EDWARDSON JM: The sigma-1 receptor binds to the Nav1.5 voltage-gated $\mathrm{Na}+$ channel with 4-fold symmetry. J Biol Chem 287: 37021-37029, 2012.

BALASURIYA D, STEWART AP, EDWARDSON JM: The $\sigma-1$ receptor interacts directly with GluN1 but not GluN2A in the GluN1/GluN2A NMDA receptor. J Neurosci 33: 18219-18224, 2013.

BALASURIYA D, D'SA L, TALKER R, DUPUIS E, MAURIN F, MARTIN P, BORGESE F, SORIANI O, EDWARDSON JM: A direct interaction between the Sigma-1 receptor and the hERG voltage-gated $\mathrm{K}+$ channel revealed by atomic force microscopy and homogeneous time-resolved fluorescence (HTRF (R)). J Biol Chem 289: 32353-32363, 2014.

BAO Q, ZHAO M, CHEN L, WANG Y, WU S, WU W, LIU X: MicroRNA-297 promotes cardiomyocyte hypertrophy via targeting sigma-1 receptor. Life Sci 175: 1-10, 2017.

BEBAROVA M, MATEJOVIC P, PASEK M, NOVAKOVA M: Effect of haloperidol on transient outward potassium current in rat ventricular myocytes. Eur J Pharmacol 550: 15-23, 2006.

BHUIYAN MS, FUKUNAGA K: Stimulation of sigma-1 receptor signaling by dehydroepiandrosterone ameliorates pressure overload-induced hypertrophy and dysfunctions in ovariectomized rats. Expert Opin Ther Targets 13: 1253-1265, 2009.

BHUIYAN MS, TAGASHIRA H, FUKUNAGA K: Crucial interactions between selective serotonin uptake inhibitors and sigma-1 receptor in heart failure. J Pharmacol Sci 121: 177-184, 2013.

BIALA AK, KIRSHENBAUM LA: The interplay between cell death signaling pathways in the heart. Trends Cardiovasc Med 24: 325-331, 2014. 
BOEHNING D, PATTERSON RL, SEDAGHAT L, GLEBOVA NO, KUROSAKI T, SNYDER SH: Cytochrome c binds to inositol $(1,4,5)$ trisphosphate receptors, amplifying calcium-dependent apoptosis. Nat Cell Biol 5: 1051-1061, 2003.

BOUCHARD P, QUIRION R: [3H]1,3-di(2-tolyl)guanidine and $[3 \mathrm{H}](+)$ pentazocine binding sites in the rat brain: autoradiographic visualization of the putative sigma1 and sigma2 receptor subtypes. Neuroscience 76: 467-477, 1997.

BRENT PJ, SAUNDERS H, DUNKLEY PR: Intrasynaptosomal free calcium levels in rat forebrain synaptosomes: modulation by sigma (sigma) receptor ligands. Neurosci Lett 211: 138-142, 1996.

CAI Y, YANG L, NIU F, LIAO K, BUCH S: Role of sigma-1 receptor in cocaine abuse and neurodegenerative disease. Adv Exp Med Biol 964: 163-175, 2017.

CHAO J, ZHANG Y, DU L, ZHOU R, WU X, SHEN K, YAO H: Molecular mechanisms underlying the involvement of the sigma-1 receptor in methamphetamine-mediated microglial polarization. Sci Rep 7: 11540, 2017.

CHU UB, MAVLYUTOV TA, CHU ML, YANG H, SCHULMAN A, MESANGEAU C, MCCURDY CR, GUO LW, RUOHO AE: The sigma-2 receptor and progesterone receptor membrane component 1 are different binding sites derived from independent genes. EBioMedicine 2: 1806-1813, 2015.

COBOS EJ, BAEYENS JM, DEL POZO E: Phenytoin differentially modulates the affinity of agonist and antagonist ligands for sigma 1 receptors of guinea pig brain. Synapse 55: 192-195, 2005.

CRITCHLEY BJ, ISALAN M, MIELCAREK M: Neuro-cardio mechanisms in Huntington's disease and other neurodegenerative disorders. Front Physiol 9: 559, 2018.

CROTTÈS D1, MARTIAL S, RAPETTI-MAUSS R, PISANI DF, LORIOL C, PELLISSIER B, MARTIN P, CHEVET E, BORGESE F, SORIANI O: Sig1R protein regulates hERG channel expression through a post-translational mechanism in leukemic cells. J Biol Chem 286: 27947-27958, 2011.

CRUMB WJ JR, EKINS S, SARAZAN RD, WIKEL JH, WRIGHTON SA, CARLSON C, BEASLEY CM JR: Effects of antipsychotic drugs on I(to), I (Na), I (sus), I (K1), and hERG: QT prolongation, structure activity relationship, and network analysis. Pharm Res 23: 1133-1143, 2006.

DALLA VECCHIA L, DE MARIA B, MARINOU K, SIDERI R, LUCINI A, PORTA A, MORA G: Cardiovascular neural regulation is impaired in amyotrophic lateral sclerosis patients. A study by spectral and complexity analysis of cardiovascular oscillations. Physiol Meas 36: 659-670, 2015.

DUMONT M, LEMAIRE S: Interaction of 1,3-di(2-[5-3H]tolyl) guanidine with sigma 2 binding sites in rat heart membrane preparations. Eur J Pharmacol 209: 245-248, 1991.

ELA C, BARG J, VOGEL Z, HASIN Y, EILAM Y: Sigma receptor ligands modulate contractility, Ca++ influx and beating rate in cultured cardiac myocytes. J Pharmacol Exp Ther 269: 1300-1309, 1994.

FIALOVA K, KRIZANOVA O, JARKOVSKY J, NOVAKOVA M: Apparent desensitization of the effects of sigma receptor ligand haloperidol in isolated rat and guinea pig hearts after chronic treatment. Can J Physiol Pharmacol 87: 1019-1027, 2009.

FONTANILLA D, JOHANNESSEN M, HAJIPOUR AR, COZZI NV, JACKSON MB, RUOHO AE: The hallucinogen N,N-dimethyltryptamine (DMT) is an endogenous sigma-1 receptor regulator. Science 323: 934-937, 2009.

FUJII K, OZEKI Y, OKAYASU H, TAKANO Y, SHINOZAKI T, HORI H, ORUI M, HORIE M, KUNUGI H, SHIMODA K: QT is longer in drug-free patients with schizophrenia compared with age-matched healthy subjects. PLoS One 9: e98555, 2014.

GAO XF, YAO JJ, HE YL, HU C, MEI YA: Sigma-1 receptor agonists directly inhibit Nav1.2/1.4 channels. PLoS One 7: e49384, 2012.

GARCIA MI, BOEHNING D: Cardiac inositol 1,4,5-trisphosphate receptors. Biochim Biophys Acta 1864: 907-914, 2017.

GLEMBOTSKI CC: Endoplasmic reticulum stress in the heart. Circ Res 101: 975-984, 2007.

GLEMBOTSKI CC: Roles for the sarco-/endoplasmic reticulum in cardiac myocyte contraction, protein synthesis, and protein quality control. Physiology (Bethesda) 27: 343-350, 2012.

GOTTLIEB SS, KHATTA M, FRIEDMANN E, EINBINDER L, KATZEN S, BAKER B, MARSHALL J, MINSHALL S, ROBINSON S, FISHER ML, POTENZA M, SIGLER B, BALDWIN C, THOMAS SA: The influence of age, gender, and race on the prevalence of depression in heart failure patients. $J$ Am Coll Cardiol 43: 1542-1549, 2004. 
HANNER M, MOEBIUS FF, FLANDORFER A, KNAUS HG, STRIESSNIG J, KEMPNER E, GLOSSMANN H: Purification, molecular cloning, and expression of the mammalian sigma1-binding site. Proc Natl Acad Sci U S A 93: 8072-8077, 1996.

HASHIMOTO K: Sigma-1 receptors and selective serotonin reuptake inhibitors: clinical implications of their relationship. Cent Nerv Syst Agents Med Chem 9: 197-204, 2009.

HASHIMOTO K: Sigma-1 receptor chaperone and brain-derived neurotrophic factor: emerging links between cardiovascular disease and depression. Prog Neurobiol 100: 15-29, 2013.

HAYASHI T, SU TP: Regulating ankyrin dynamics: roles of sigma-1 receptors. Proc Natl Acad Sci U S A8: 491-496, 2001.

HAYASHI T, SU TP: Intracellular dynamics of sigma-1 receptors (sigma(1) binding sites) in NG108-15 cells. J Pharmacol Exp Ther 306: 726-733, 2003.

HAYASHI T, SU TP: Sigma-1 receptor ligands: potential in the treatment of neuropsychiatric disorders. CNS Drugs 18: $269-284,2004$.

HAYASHI T, SU TP: Sigma-1 receptor chaperones at the ER-mitochondrion interface regulate $\mathrm{Ca}(2+)$ signaling and cell survival. Cell 131: 596-610, 2007.

HELLEWELL SB, BOWEN WD: A sigma-like binding site in rat pheochromocytoma (PC12) cells: decreased affinity for (+)-benzomorphans and lower molecular weight suggest a different sigma receptor form from that of guinea pig brain. Brain Res 527: 244-253, 1990.

HELLEWELL SB, BRUCE A, FEINSTEIN G, ORRINGER J, WILLIAMS W, BOWEN WD: Rat liver and kidney contain high densities of sigma 1 and sigma 2 receptors: characterization by ligand binding and photoaffinity labeling. Eur J Pharmacol 268: 9-18, 1994.

HLAVÁČOVÁ M, OLEJNÍČKOVÁ V, RONZHINA M, STRAČINA T, JANOUŠEK O, NOVÁKOVÁ M, BABULA P, KOLÁR̆OVÁ J, PROVAZNÍK I, PAULOVÁ H: Tolerance of isolated rabbit hearts to short ischemic periods is affected by increased LV mass fraction. Physiol Res 66: 581-589, 2017.

HUANG Y, ZHENG L, HALLIDAY G, DOBSON-STONE C, WANG Y, TANG HD, CAO L, DENG YL, WANG G, ZHANG YM, WANG JH, HALLUPP M, KWOK J, CHEN SD: Genetic polymorphisms in sigma-1 receptor and apolipoprotein E interact to influence the severity of Alzheimer's disease. Curr Alzheimer Res 8: 765-770, 2011.

ITO K, HIROOKA Y, MATSUKAWA R, NAKANO M, SUNAGAWA K: Decreased brain sigma-1 receptor contributes to the relationship between heart failure and depression. Cardiovasc Res 93: 33-40, 2012.

ITO K, HIROOKA Y, SUNAGAWA K: Brain sigma-1 receptor stimulation improves mental disorder and cardiac function in mice with myocardial infarction. J Cardiovasc Pharmacol 62: 222-228, 2013.

JOHANNESSEN M, FONTANILLA D, MAVLYUTOV T, RUOHO AE, JACKSON MB: Antagonist action of progesterone at $\sigma$-receptors in the modulation of voltage-gated sodium channels. Am J Physiol Cell Physiol 300: C328-C337, 2011.

JOHANNESSEN M, RAMACHANDRAN S, RIEMER L, RAMOS-SERRANO A, RUOHO AE, JACKSON MB: Voltage-gated sodium channel modulation by sigma-receptors in cardiac myocytes and heterologous systems. Am J Physiol Cell Physiol 296: C1049-C1057, 2009.

KATCHMAN AN, KOERNER J, TOSAKA T, WOOSLEY RL, EBERT SN: Comparative evaluation of HERG currents and QT intervals following challenge with suspected torsadogenic and nontorsadogenic drugs. J Pharmacol Exp Ther 316: 1098-1106, 2006.

KEKUDA R, PRASAD PD, FEI YJ, LEIBACH FH, GANAPATHY V: Cloning and functional expression of the human type 1 sigma receptor (hSigmaR1). Biochem Biophys Res Commun 229: 553-558, 1996.

KOCKSKÄMPER J, ZIMA AV, RODERICK HL, PIESKE B, BLATTER LA, BOOTMAN MD: Emerging roles of inositol 1,4,5-trisphosphate signaling in cardiac myocytes. J Mol Cell Cardiol 45: 128-147, 2008.

KUBICKOVA J, LENCESOVA L, CSADEROVA L, STRACINA T, HUDECOVA S, BABULA P, ROZBORILOVA E, NOVAKOVA M, KRIZANOVA O: Haloperidol affects plasticity of differentiated NG-108 cells through б1R/IP. Cell Mol Neurobiol 38: 181-194, 2018.

KUSHNER L, ZUKIN RS: The sigma receptors: concluding remarks/future visitas. In: Sigma Receptors. ITZHAK Y (ed.), Academic Press, London, UK, 1994, pp 319-333. 
LAURINI E, COL VD, MAMOLO MG, ZAMPIERI, POSOCCO P, FERMEGLIA M, VIO L, PRICL S: Homology model and docking-based virtual screening for ligands of the $\sigma 1$ receptor. ACS Med Chem Lett 2: 834-839, 2011.

LAURINI E, MARSON D, FERMEGLIA M, PRICL S: 3D homology model of sigma1 receptor. Handb Exp Pharmacol 244: 27-50, 2017.

LEONARD CE, FREEMAN CP, NEWCOMB CW, BILKER WB, KIMMEL SE, STROM BL, HENNESSY S: Antipsychotics and the risks of sudden cardiac death and all-cause death: cohort studies in medicaid and dually-eligible medicaid-medicare beneficiaries of five states. J Clin Exp Cardiolog (Suppl 10): 1-9, 2013.

LEUCHT S, CIPRIANI A, SPINELI L, MAVRIDIS D, OREY D, RICHTER F, SAMARA M, BARBUI C, ENGEL RR, GEDDES JR, KISSLING W, STAPF MP, LÄSSIG B, SALANTI G, DAVIS JM: Comparative efficacy and tolerability of 15 antipsychotic drugs in schizophrenia: a multiple-treatments meta-analysis. Lancet 382: 951-962, 2013.

LI X, HU Z, LIU L, XIE Y, ZHAN Y, ZI X, WANG J, WU L, XIA K, TANG B, ZHANG R: A SIGMAR1 splice-site mutation causes distal hereditary motor neuropathy. Neurology 84: 2430-2437, 2015.

LIU MQ, CHEN Z, CHEN LX: Endoplasmic reticulum stress: a novel mechanism and therapeutic target for cardiovascular diseases. Acta Pharmacol Sin 37: 425-443, 2016.

LIU X, FU Y, YANG H, MAVLYUTOV T, LI J, MCCURDY CR, GUO LW, PATTNAIK BR: Potential independent action of sigma receptor ligands through inhibition of the Kv2.1 channel. Oncotarget 8: 59345-59358, 2017.

LUTY AA, KWOK JB, DOBSON-STONE C, LOY CT, COUPLAND KG, KARLSTRÖM H, SOBOW T, TCHORZEWSKA J, MARUSZAK A, BARCIKOWSKA M, PANEGYRES PK, ZEKANOWSKI C, BROOKS WS, WILLIAMS KL, BLAIR IP, MATHER KA, SACHDEV PS, HALLIDAY GM, SCHOFIELD PR: Sigma nonopioid intracellular receptor 1 mutations cause frontotemporal lobar degeneration-motor neuron disease. Ann Neurol 68: 639-649, 2010.

MANDELLI L, WANG SM, HAN C, LEE SJ, PATKAR AA, MASAND PS, PAE CU, SERRETTI A: The impact of a single nucleotide polymorphism in SIGMAR1 on depressive symptoms in major depressive disorder and bipolar disorder. Adv Ther 34: 713-724, 2017.

MARTIN RL, MCDERMOTT JS, SALMEN HJ, PALMATIER J, COX BF, GINTANT GA: The utility of hERG and repolarization assays in evaluating delayed cardiac repolarization: influence of multi-channel block. J Cardiovasc Pharmacol 43: 369-379, 2004.

MARTIN WR, EADES CG, THOMPSON JA, HUPPLER RE, GILBERT PE: The effects of morphine- and nalorphinelike drugs in the nondependent and morphine-dependent chronic spinal dog J Pharmacol Exp Ther 197: 517-532, 1976.

MAURICE T, SU TP: The pharmacology of sigma-1 receptors. Pharmacol Ther 124: 195-206, 2009.

MAVLYUTOV TA, EPSTEIN ML, VERBNY YI, HUERTA MS, ZAITOUN I, ZISKIND-CONHAIM L, RUOHO AE: Lack of sigma-1 receptor exacerbates ALS progression in mice. Neuroscience 240: 129-134, 2013.

MAVLYUTOV TA, RUOHO AE: Ligand-dependent localization and intracellular stability of sigma-1 receptors in CHO-K1 cells. J Mol Signal 2: 8, 2007.

MAVLYUTOV, TIMUR A, GUO LW, EPSTEIN ML, RUOHO AE: Role of the sigma-1 receptor in Amyotrophic Lateral Sclerosis (ALS). J Pharmacol Sci 127: 10-16, 2015.

MEI J, PASTERNAK GW: Molecular cloning and pharmacological characterization of the rat sigmal receptor. Biochem Pharmacol 62: 349-355, 2001.

MEI J, PASTERNAK GW: Sigma1 receptor modulation of opioid analgesia in the mouse. J Pharmacol Exp Ther 300: 1070-1074, 2002.

MISHRA, AK, MAVLYUTOV T, SINGH DR, BIENER G, YANG J, OLIVER JA, RUOHO A, RAICU V: The sigma-1 receptors are present in monomeric and oligomeric forms in living cells in the presence and absence of ligands. Biochem J 466: 263-271, 2015.

MITSUDA T, OMI T, TANIMUKAI H, SAKAGAMI Y, TAGAMI S, OKOCHI M, KUDO T, TAKEDA M: Sigma-1Rs are upregulated via PERK/eIF2 $\alpha /$ ATF4 pathway and execute protective function in ER stress. Biochem Biophys Res Commun 415: 519-525, 2011.

MOEBIUS FF, STRIESSNIG J, GLOSSMANN H: The mysteries of sigma receptors: new family members reveal a role in cholesterol synthesis. Trends Pharmacol Sci 18: 67-70, 1997. 
MONASSIER L, MANOURY B, BELLOCQ C, WEISSENBURGER J, GRENEY H, ZIMMERMANN D, EHRHARDT JD, JAILLON P, BARÓ I, BOUSQUET P: Sigma(2)-receptor ligand-mediated inhibition of inwardly rectifying $\mathrm{K}(+)$ channels in the heart. J Pharmacol Exp Ther 322: 341-350, 2007.

MORI T, HAYASHI T, HAYASHI E, SU TP: Sigma-1 receptor chaperone at the ER-mitochondrion interface mediates the mitochondrion-ER-nucleus signaling for cellular survival. PLoS One 8: e76941, 2013.

MORTL D, AGNETER E, KRIVANEK P, KOPPATZ K, TODT H: Dual rate-dependent cardiac electrophysiologic effects of haloperidol: Slowing of intraventricular conduction and lengthening of repolarization. $J$ Cardiovasc Pharmacol 41: 870-879, 2003.

NAVARRO G, MORENO E, AYMERICH M, MARCELLINO D, MCCORMICK PJ, MALLOL J, CORTÉS A, CASADÓ V, CANELA EI, ORTIZ J, FUXE K, LLUÍS C, FERRÉ S, FRANCO R: Direct involvement of sigma-1 receptors in the dopamine D1 receptor-mediated effects of cocaine. Proc Natl Acad Sci U S A 107: 18676-18681, 2010.

NAVARRO G, MORENO E, BONAVENTURA J, BRUGAROLAS M, FARRÉ D, AGUINAGA D, MALLOL J, CORTÉS A, CASADÓ V, LLUÍS C, FERRE S, FRANCO R, CANELA E, MCCORMICK PJ: Cocaine inhibits dopamine D2 receptor signaling via sigma-1-D2 receptor heteromers. PLoS One 8: e61245, 2013.

NGUYEN L, ROBSON MJ, HEALY JR, SCANDINARO AL, MATSUMOTO RR: Involvement of sigma-1 receptors in the antidepressant-like effects of dextromethorphan. PLoS One 9: e89985, 2014.

NICHOLS DE: N,N-dimethyltryptamine and the pineal gland: Separating fact from myth. $J$ Psychopharmacol 32: 30-36, 2018.

NOLANO M, PROVITERA V, MANGANELLI F, IODICE R, CAPORASO G, STANCANELLI A, MARINOU K, LANZILLO B, SANTORO L, MORA G: Non-motor involvement in amyotrophic lateral sclerosis: new insight from nerve and vessel analysis in skin biopsy. Neuropathol Appl Neurobiol 43: 119-132, 2017.

NOVAKOVA M, BRUDEROVA V, SULOVA Z, KOPACEK J, LACINOVA L, KVETNANSKY R, VASKU A, KAPLAN P, KRIZANOVA O, JURKOVICOVA D: Modulation of expression of the sigma receptors in the heart of rat and mouse in normal and pathological conditions. Gen Physiol Biophys 26: 110-117, 2007.

NOVAKOVA M, ELA C, BARG J, VOGEL Z, HASIN Y, EILAM Y: Inotropic action of sigma receptor ligands in isolated cardiac myocytes from adult rats. Eur J Pharmacol 286: 19-30, 1995.

NOVAKOVA M, ELA C, BOWEN WD, HASIN Y, EILAM Y: Highly selective sigma receptor ligands elevate inositol 1,4,5-trisphosphate production in rat cardiac myocytes. Eur J Pharmacol 353: 315-327, 1998.

NOVAKOVA M, SEDLAKOVA B, SIROVA M, FIALOVA K, KRIZANOVA O: Haloperidol increases expression of the inositol 1,4,5-trisphosphate receptors in rat cardiac atria, but not in ventricles. Gen Physiol Biophys 29: 381-389, 2010.

PABBA M: The essential roles of protein-protein interaction in sigma-1 receptor functions. Front Cell Neurosci 7: 50, 2013.

PATTERSON TA, CONNOR M, CHAVKIN CH: Recent evidence for endogenous substance(s) for sigma receptors. In: Sigma Receptors. ITZHAK Y (ed.), Academic Press Inc., San Diego, CA, 1994, pp 171-190.

PEETERS M, ROMIEU P, MAURICE T, SU TP, MALOTEAUX JM, HERMANS E: Involvement of the sigma 1 receptor in the modulation of dopaminergic transmission by amantadine. Eur J Neurosci 19: 2212-2220, 2004.

PENKE B, FULOP L, SZUCS M, FRECSKA E: The role of sigma-1 receptor, an intracellular chaperone in neurodegenerative diseases. Curr Neuropharmacol 16: 97-116, 2018.

PERNEY TM, KACZMAREK LK: The molecular biology of K+ channels. Curr Opin Cell Biol 3: 663-670, 1991.

PRASAD PD, LI HW, FEI YJ, GANAPATHY ME, FUJITA T, PLUMLEY LH, YANG-FENG TL, LEIBACH FH, GANAPATHY V: Exon-intron structure, analysis of promoter region, and chromosomal localization of the human type 1 sigma receptor gene. J Neurochem 70: 443-451, 1998.

QUIRION R, BOWEN WD, ITZHAK Y, JUNIEN JL, MUSACCHIO JM, ROTHMAN RB, SU TP, TAM SW, TAYLOR DP: A proposal for the classification of sigma binding sites. Trends Pharmacol Sci 13: 85-86, 1992.

RAUDENSKA M, GUMULEC J, BABULA P, STRACINA T, SZTALMACHOVA M, POLANSKA H, ADAM V, KIZEK R, NOVAKOVA M, MASARIK M: Haloperidol cytotoxicity and its relation to oxidative stress. Mini Rev Med Chem 13: 1993-1998, 2013.

ROBSON MJ, ELLIOTT M, SEMINERIO MJ, MATSUMOTO RR: Evaluation of sigma $(\sigma)$ receptors in the antidepressant-like effects of ketamine in vitro and in vivo. Eur Neuropsychopharmacol 22: 308-317, 2012. 
RUMSFELD JS, HAVRANEK E, MASOUDI FA, PETERSON ED, JONES P, TOOLEY JF, KRUMHOLZ JM, SPERTUS JA, CARDIOVASCULAR OUTCOMES RESEARCH CONSORTIUM: Depressive symptoms are the strongest predictors of short-term declines in health status in patients with heart failure. $\mathrm{J} \mathrm{Am} \mathrm{Coll} \mathrm{Cardiol}$ 42: 1811-1817, 2003.

SÁNCHEZ-FERNÁNDEZ C, MONTILLA-GARCÍA Á, GONZÁLEZ-CANO R, NIETO FR, ROMERO L, ARTACHO-CORDÓN A, MONTES R, FERNÁNDEZ-PASTOR B, MERLOS M, BAEYENS JM, ENTRENA JM, COBOS EJ: Modulation of peripheral $\mu$-opioid analgesia by $\sigma 1$ receptors. $J$ Pharmacol Exp Ther 348: 32-45, 2014.

SCHLEIFER SJ, MACARI-HINSON MM, COYLE DA, SLATER WR, KAHN M, GORLIN R, ZUCKER HD: The nature and course of depression following myocardial infarction. Arch Intern Med 149: 1785-1789, 1989.

SCHMIDT HR, ZHENG S, GURPINAR E, KOEHL A, MANGLIK A, KRUSE AC: Crystal structure of the human $\sigma 1$ receptor. Nature 532: 527-530, 2016.

SCHUSTER DI, ARNOLD FJ, MURPHY RB: Purification, pharmacological characterization and photoaffinity labeling of sigma receptors from rat and bovine brain. Brain Res 670: 14-28, 1995.

SETH P, FEI YJ, LI HW, HUANG W, LEIBACH FH, GANAPATHY W: Cloning and functional characterization of a sigma receptor from rat brain. J Neurochem 70: 922-931, 1998.

SETH P, LEIBACH FH, GANAPATHY V: Cloning and structural analysis of the cDNA and the gene encoding the murine type 1 sigma receptor. Biochem Biophys Res Commun 241: 535-540, 1997.

SHIMIZU I, MINAMINO T: Physiological and pathological cardiac hypertrophy. J Mol Cell Cardiol 97: 245-262, 2016.

SHINODA Y, TAGASHIRA H, BHUIYAN MS, HASEGAWA H, KANAI H, FUKUNAGA K: Haloperidol aggravates transverse aortic constriction-induced heart failure via mitochondrial dysfunction. $J$ Pharmacol Sci 131: 172-183, 2016.

SHINODA Y, TAGASHIRA H, BHUIYAN MS, HASEGAWA H, KANAI H, ZHANG C, HAN F, FUKUNAGA K: Corticosteroids mediate heart failure-induced depression through reduced $\sigma 1$-receptor expression. PLoS One 11: $\mathrm{e} 0163992,2016$.

STRACINA T, RONZHINA M, STARK T, RUDA J, OLSANSKA E, VESELY P, MICALE V, NOVAKOVA M, MURRAY A: Prolonged QT interval in neurodevelopmental rat model of schizophrenia. Computing in Cardiology Conference 2016 (Cinc) 43: 1049-1052, 2016.

STRACINA T, SLANINOVA I, POLANSKA H, AXMANOVA M, OLEJNICKOVA V, KONECNY P, MASARIK M, KRIZANOVA O, NOVAKOVA M: Long-term haloperidol treatment prolongs QT interval and increases expression of sigma 1 and IP3 receptors in guinea pig hearts. Tohoku J Exp Med 236: 199-207, 2015.

SU TP: Evidence for sigma opioid receptor: binding of [3H]SKF-10047 to etorphine-inaccessible sites in guinea-pig brain. J Pharmacol Exp Ther 223: 284-290, 1982.

SU TP, HAYASHI T: Understanding the molecular mechanism of sigma-1 receptors: towards a hypothesis that sigma-1 receptors are intracellular amplifiers for signal transduction. Curr Med Chem 10: 2073-2080, 2003.

SU TP, HAYASHI T, MAURICE T, BUCH S, RUOHO AE: The sigma-1 receptor chaperone as an inter-organelle signaling modulator. Trends Pharmacol Sci 31: 557-566, 2010.

SU TP, SU TC, NAKAMURA Y, TSAI SY: The sigma-1 receptor as a pluripotent modulator in living systems. Trends Pharmacol Sci 37: 262-278, 2016.

SUESSBRICH H, SCHÖNHERR R, HEINEMANN SH, ATTALI B, LANG F, BUSCH AE: The inhibitory effect of the antipsychotic drug haloperidol on HERG potassium channels expressed in Xenopus oocytes. Br J Pharmacol 120: 968-974, 1997.

TAGASHIRA H, BHUIYAN MS, FUKUNAGA K: Diverse regulation of IP3 and ryanodine receptors by pentazocine through $\sigma 1$-receptor in cardiomyocytes. Am J Physiol Heart Circ Physiol 305: H1201-H1212, 2013.

TAGASHIRA H, BHUIYAN MS, SHIODA N, FUKUNAGA K: Fluvoxamine rescues mitochondrial Ca2+ transport and ATP production through o(1)-receptor in hypertrophic cardiomyocytes. Life Sci 95: 89-100, 2014.

TAGASHIRA H, ZHANG C, LU YM, HASEGAWA H, KANAI H, HAN F, FUKUNAGA K: Stimulation of $\sigma 1$-receptor restores abnormal mitochondrial $\mathrm{Ca}^{2+}$ mobilization and ATP production following cardiac hypertrophy. Biochim Biophys Acta 1830: 3082-3094, 2013. 
TAM SW: Naloxone-inaccessible sigma receptor in rat central nervous system. Proc Natl Acad Sci U S A 80: 6703-7670, 1983.

TARABOVA B, NOVAKOVA M, LACINOVA L: Haloperidol moderately inhibits cardiovascular L-type calcium current. Gen Physiol Biophys 28: 249-259, 2009.

TCHEDRE KT, HUANG RQ, DIBAS A, KRISHNAMOORTHY RR, DILLON GH, YORIO T: Sigma-1 receptor regulation of voltage-gated calcium channels involves a direct interaction. Invest Ophthalmol Vis Sci 49: 4993-5002, 2008.

TORRENCE-CAMPBELL C, BOWEN WD: Differential solubilization of rat liver sigma 1 and sigma 2 receptors: retention of sigma 2 sites in particulate fractions. Eur J Pharmacol 304: 201-210, 1996.

TREBATICKÁ J, DUKÁT A, ĎURAČKOVÁ Z, MUCHOVÁ J: Cardiovascular diseases, depression disorders and potential effects of omega-3 fatty acids. Physiol Res 66: 363-382, 2017.

VAN WAARDE A, RYBCZYNSKA AA, RAMAKRISHNAN NK, ISHIWATA K, ELSINGA PH, DIERCKX RA: Potential applications for sigma receptor ligands in cancer diagnosis and therapy. Biochim Biophys Acta 1848: 2703-2714, 2015.

VUCIC S: Sensory and autonomic nervous system dysfunction in amyotrophic lateral sclerosis. Neuropathol Appl Neurobiol 43: 99-101, 2017.

WANG JP, CHI RF, LIU J, DENG YZ, HAN XB, QIN FZ, LI B: The role of endogenous reactive oxygen species in cardiac myocyte autophagy. Physiol Res 67: 31-40, 2018.

WANG ZV, DENG Y, GAO N, PEDROZO Z, LI DL, MORALES CR, CRIOLLO A, LUO X, TAN W, JIANG N, LEHRMAN MA, ROTHERMEL BA, LEE AH, LAVANDERO S, MAMMEN PPA, FERDOUS A, GILLETTE TG, SCHERER PE, HILL JA: Spliced X-box binding protein 1 couples the unfolded protein response to hexosamine biosynthetic pathway. Cell 156: 1179-1192, 2014.

WOLFE SA, CULP SG, DE SOUZA EB: Sigma-receptors in endocrine organs: identification, characterization, and autoradiographic localization in rat pituitary, adrenal, testis, and ovary. Endocrinology 124: 1160-1172, 1989.

WU CS, TSAI YT, TSAI HJ: Antipsychotic drugs and the risk of ventricular arrhythmia and/or sudden cardiac death: a nation-wide case-crossover study. J Am Heart Assoc 4: pii: e001568, 2015.

WU Z, BOWEN WD: Role of sigma-1 receptor C-terminal segment in inositol 1,4,5-trisphosphate receptor activation: constitutive enhancement of calcium signaling in MCF-7 tumor cells. J Biol Chem 283: 28198-28215, 2008.

XU J, ZENG C, CHU W, PAN F, ROTHFUSS JM, ZHANG F, TU Z, ZHOU D, ZENG D, VANGVERAVONG S, JOHNSTON F, SPITZER D, CHANG KC, HOTCHKISS RS, HAWKINS WG, WHEELER KT, MACH RH: Identification of the PGRMC1 protein complex as the putative sigma-2 receptor binding site. Nat Commun 2: $380,2011$.

ZENG C, ROTHFUSS J, ZHANG J, CHU W, VANGVERAVONG S, TU Z, PAN F, CHANG KC, HOTCHKISS R, MACH RH: Sigma-2 ligands induce tumour cell death by multiple signalling pathways. Br $J$ Cancer 106: 693-701, 2012.

ZHANG H, CUEVAS J: Sigma receptor activation blocks potassium channels and depresses neuroexcitability in rat intracardiac neurons. J Pharmacol Exp Ther 313: 1387-1396, 2005.

ZHANG CL, FENG ZJ, LIU Y, JI XH, PENG JY, ZHANG XH, ZHEN XC, LI BM: Methylphenidate enhances NMDA-receptor response in medial prefrontal cortex via sigma-1 receptor: a novel mechanism for methylphenidate action. PLoS One 7: e51910, 2012. 